\title{
LITERASI LAPORAN KEUANGAN IBU-IBU WIROGUNAN YOGYAKARTA
}

\author{
Jajuk Herawati, Siti Sumartiah, Pristin Prima Sari, Destri Wulandari \\ Fakultas Ekonomi Universitas Sarjanawiyata Tamansiswa, Jl.Kusumanegara No 121 \\ Yogyakarta, 55165, Indonesia \\ E-mail: jajuk.herawati@ustjogja.ac.id
}

\begin{abstract}
ABSTRAK
Laporan keuangan penting bagi setiap pelaku usaha dan keluarga karena diperlukan untuk sumber informasi keuangan. Ibu-Ibu Wirogunan sebagian besar tidak membuat laporan keuangan bisnis dengan baik sehingga pelatihan laporan keuangan sangat diperlukan untuk disosialisasikan kepada Ibu-Ibu pelaku bisnis di Wirogunan. Kegiatan pengabdian kepada masyarakat ini bertujuan untuk meningkatkan literasi laporan keuangan melalui kegiatan pelatihan laporan keuangan kepada Ibu-Ibu Wirogunan Yogyakarta. Metode kegiatan adalah ceramah, tanya-jawab dan praktek laporan keuangan. Kegiatan dilaksanakan di Kelurahan Wirogunan Yogyakarta. Hasil kegiatan adalah IbuIbu Wirogunan mengalami peningkatan pemahaman laporan keuangan dengan baik sebesar $48 \%$ dengan nilai akhir sebesar 85 . Manfaat kegiatan adalah IbuIbu Wirogunan Yogyakarta dapat tertib dalam membuat laporan keuangan usaha kecil. Luaran hasil pengabdian adalah brosur laporan keuangan usaha kecil.
\end{abstract}

Kata kunci: laporan keuangan, literasi, pengabdian

\section{ABSTRACTS}

Financial reports become useful for every business actor and family because of financial information sources. Most of the Wirogunan women have little knowledge in making business financial reports so that training in financial reporting being valuable to disseminate for business people and families. This community service activity aims to provide training on financial reports to Wirogunan Yogyakarta women. The methods of activity are lectures, question-and-answer, and financial reporting practice. The results showed that increasing knowledge of financial reports for Women in Wirogunan. The benefit of this activity is that Wirogunan Yogyakarta women can be orderly in making small business financial reports. The output of this dedication is a small business financial report booklet.

Keywords: community services, financial reports, literation 


\section{PENDAHULUAN}

Literasi laporan keuangan merupakan sebuah keharusan bagi setiap pelaku usaha kecil. Perilaku keuangan usaha kecil umumnya tidak memiliki laporan keuangan (Mumpuni, 2019). Jika tidak ada laporan keuangan maka sebuah bisnis tidak dapat tertib dalam keuangan bisnis. Ketidaktertiban ini menyebabkan usaha kecil tidak dapat menentukan biaya, aliran kas masuk dan keluar dengan baik.

Faktor yang menjadi dasar usaha kecil tidak membuat laporan keuangan antara lain usaha kecil belum memiliki pemahaman yang baik tentang laporan keuangan bisnis dan keterbatasan pelatihan laporan keuangan bagi usaha kecil sehingga usaha kecil kekurangan akses terhadap informasi pembuatan laporan keuangan. Keterbatasan informasi laporan keuangan menjadi sebab literasi laporan keuangan menjadi rendah. Cara untuk meningkatkan literasi laporan keuangan terhadap usaha kecil adalah dengan mengadakan pelatihan dan sosialisasi tentang pentingnya pembuatan laporan keuangan dalam bisnis. Oleh karena itu, pemahaman tentang laporan keuangan perlu disampaikan kepada para pelaku usaha kecil.

Laporan keuangan sangat diperlukan dalam sebuah bisnis baik skala besar atau kecil. Manfaat laporan keuangan untuk usaha kecil adalah untuk menentukan kondisi keuangan, untuk mengetahui laba/rugi, untuk menentukan harga jual dan untuk menentukan pengambilan keputusan bisnis.
Laporan keuangan juga dapat memberikan informasi kelayakan sebuah bisnis melalui perolehan profitabilitas dan arus kas masuk. Proyeksi Profitabilitas dan arus kas merupakan bentuk studi kelayakan bisnis (Kurniawan dan Rinofah, 2018).

Pembuatan laporan keuangan juga mendorong perilaku disiplin keuangan. Disipin keuangan mendorong kelancaran kegiatan operasional dan keberhasilan bisnis. Manfaat disiplin keuangan adalah dapat mengendalikan biaya tambahan, dapat menghindari kehilangan aliran kas masuk dan kelebihan aliran kas keluar, dapat menghindari kesalahan pencatatan keuangan, dapat menghindari potensi kerugian yang lebih besar dan menghindari penipuan dalam operasional bisnis.

Ibu-Ibu Wirogunan sebagian besar merupakan pelaku bisnis sehingga Ibu-Ibu Wirogunan memerlukan laporan keuangan untuk memantau kondisi keuangan dan keputusan bisnis. Namun, Ibu-Ibu Wirogunan yang sebagian besar merupakan pelaku bisnis tidak membuat laporan keuangan bisnis. Mereka tidak memiliki pemahaman yang baik tentang laporan keuangan bisnis. Hal ini disebabkan oleh kurangnya akses terhadap manajemen keuangan bisnis dan tingkat pendidikan para Ibu-Ibu Wirogunan.

Kegiatan pelatihan melalui program pengabdian kepada masyarakat akan membentuk jaringan antara masyarakat dan Perguruan Tinggi. Kegiatan pengabdian kepada masyarakat dari Perguruan Tinggi juga merupakan 
bentuk mentoring terhadap masyarakat dan membentuk sebuah ikatan komunitas antara Ibu-Ibu PKK dan Perguruan Tinggi. Cari mentor dan bergabung komunitas merupakan kunci sukses berbisnis (Abadi, 2016). Sebuah komunitas dan seorang mentor dapat menjadi referensi dan jaringan bisnis sehingga mendorong keberhasilan bisnis. Profil sebuah bisnis 91,43\% dipengaruhi oleh referensi dan jaringan (Hermuningsih et al., 2017).

Program pelatihan ini juga diharapkan dapat membentuk profil sebuah bisnis bagi Ibu-Ibu Wirogunan. Kegiatan pelatihan juga dapat menambah wawasan bagi IbuIbu Wirogunan. Membuka wawasan merupakan salah satu cara untuk sukses berbisnis (Sari, 2019). Selain membuka wawasan, kegiatan pengadian juga dapat meningkatkan literasi keuangan yaitu pemahaman terhadap bidang keuangan kepada Ibu-Ibu Wirogunan.

Faktor pendorong kegiatan pelatihan diantaranya adalah Ibu-Ibu secara umum memiliki tingkat pemahaman pembukuan dan penganggaran masih rendah (Cahyani et al., 2019). Untuk itu, pelatihan pembuatan dan pemahaman laporan keuangan terhadap Ibu-Ibu penting untuk dilaksanakan. Disamping itu, praktek mengelola keuangan dapat meningkatkan keberhasilan finansial dan kepuasan finansial para pedagang (Rinofah dan Sari, 2019). Semakin baik mengelola keuangan maka keberhasilan keuangan juga meningkat dan mencapai tingkat kepuasan. Pembuatan laporan keuangan merupakan salah satu bentuk praktek mengelola keuangan sehingga diharapkan dengan adanya tertib keuangan dengan membuat laporan keuangan maka kesejahteraan finansial dapat dicapai (Gambar 1).

Laporan keuangan juga dapat mempengaruhi kinerja bisnis dan kompetensi bagi Ibu-Ibu pelaku bisnis. Abdillah et al., (2019) menemukan bahwa pengetahuan akuntansi melalui laporan keuangan dapat meningkatkan kinerja bisnis. Upaya peningkatan kualitas sumber daya manusia dapat dilakukan melalui program pengabdian kepada masyarakat perguruan tinggi (Widarwati et al., 2017). Kegiatan pelatihan kepada masyarakat juga merupakan kegiatan pemberdayaan masyarakat untuk meningkatkan kesejahteraan (Herawati et al., 2019).

Identifikasi Masalah adalah bagaimana cara membuat laporan keuangan untuk bisnis bagi Ibu-Ibu Masyarakat Kelurahan Wirogunan di Yogyakarta dan strategi tertib Keuangan untuk bisnis dan keluarga. Tujuan Pengabdian adalah Untuk menumbuhkan disiplin keuangan bisnis dan untuk melatih membuat laporan keuangan untuk bisnis keluarga Ibu-Ibu Masyarakat Kelurahan Wirogunan di Yogyakarta. Manfaat Pengabdian Bagi Mitra Pengabdian adalah Ibu-Ibu Kelurahan Wirogunan dapat tertib dalam keuangan bisnis dan keluarga dan dapat membuat laporan keuangan. 


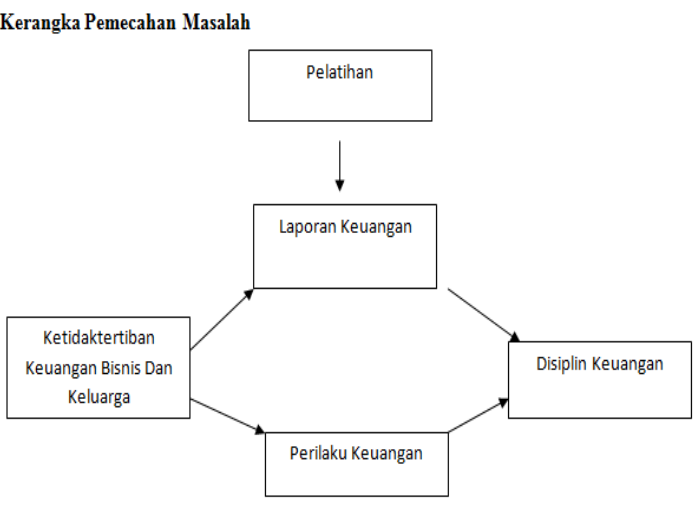

Gambar 1. Kerangka Pemikiran

\section{METODE}

Metode

pelaksanaan pengabdian adalah ceramah dan praktek. Sasaran Kegiatan adalah IbuIbu Kelurahan Wirogunan Yogyakarta. Keterkaitan dengan mitra pengabdian adalah 1) Ibu-Ibu Kelurahan Wirogunan berperan sebagai sasaran ABDIMAS yang akan diberikan pelatihan laporan keuangan dengan tujuan agar tertib keuangan bisnis, 2) Tim ABDIMAS Universitas Sarjanawiyata

Tamansiswa Yogyakarta yang berperan sebagai penyelenggara mendapatkan manfaat sosial dan Praktek dimasyarakat. Waktu Kegiatan selama dua hari antara lain sebagai berikut Hari Pertama pada hari Senin, 05 Agustus 2019 (materi tentang laporan keuangan), sedangkan hari kedua pada hari Selasa, 06 Agustus 2019 (materi tentang disiplin keuangan). Lokasi kegiatan terletak di Kelurahan Wirogunan Kota Yogyakarta. Desain Alat menggunakan Papan tulis, spidol dan perlengkapan. Indikator Keberhasilan adalah Ibu-Ibu Kelurahan Wirogunan dapat disiplin dalam keuangan dan Ibu-Ibu Kelurahan Wirogunan dapat membuat laporan keuangan.
Peserta pelatihan adalah Ibu-Ibu Kelurahan Wirogunan di Yogyakarta. Ibu-Ibu Kelurahan Wirogunan terdiri dari beranekaragam budaya dan hidup harmonis. Ibu-Ibu Kelurahan Wirogunan sebagian besar mengelola bisnis. Pelatihan laporan keuangan bisnis akan meningkatkan ketertiban dan disiplin keuangan bisnis dan keluarga bagi Ibu-Ibu Wirogunan.

\section{HASIL DAN PEMBAHASAN}

\section{Pelaksanaan Kegiatan}

Hari pertama kegiatan adalah laporan keuangan usaha kecil. Laporan keuangan berguna untuk menentukan kebijakan keuangan. Laporan keuangan dapat mengetahui kesehatan keuangan usaha kecil seperti laba atau rugi. Usaha kecil seharusnya mencatat laporan keuangan secara tertib. Usaha kecil dapat menerapkan kedisiplinan dalam hal keuangan.

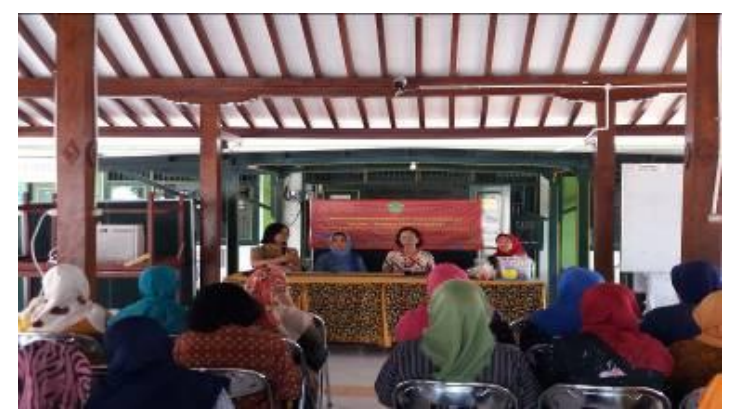

Gambar 2. Sambutan Ibu Lurah

Pada hari kedua, tanggal 6 Agustus 2019 acara dilanjutkan dengan materi pentingnya disiplin keuangan bisnis. Teknik untuk disiplin bisnis antara lain adalah memisahkan laporan keuangan bisnis dan keluarga, menganggarkan pengeluaran tambahan, menghindari uang menginap pada karyawan, tidak menggandakan deskripsi pekerjaan kasir dengan bidang lainnya. Strategi 
untuk tertib keuangan adalah memisahkan keuangan dengan kasir, menghindarkan uang menginap pada karyawan, cek stok secara berkala, cek kebutuhan dan pendapatan dimasa mendatang (Setiabudi, 2008).

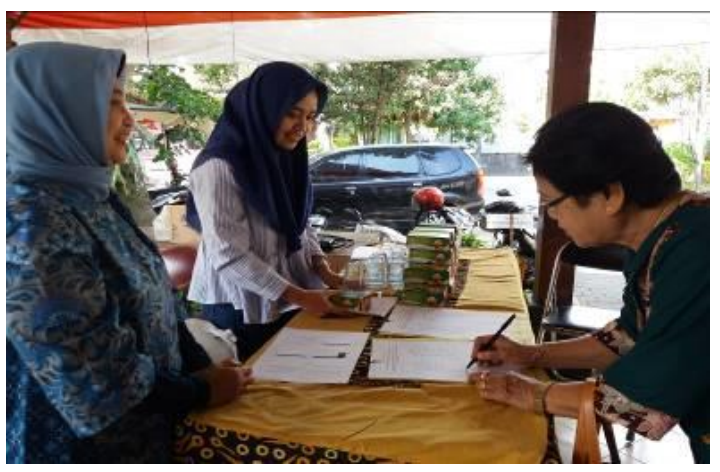

Gambar 3. Presensi Peserta

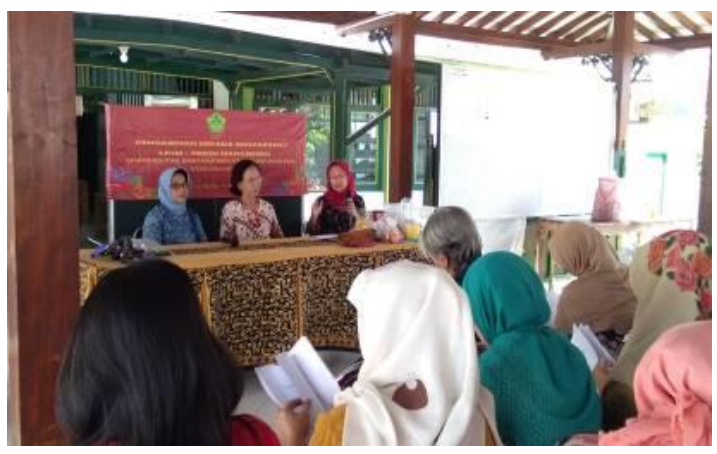

Gambar 4. Materi Keuangan

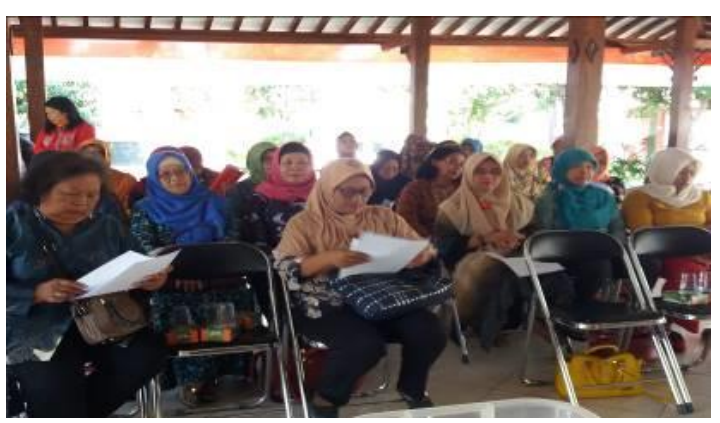

Gambar 5. Peserta Kegiatan

\section{Brosur Pedoman Laporan Keuangan}

Pembuatan panduan laporan keuangan bertujuan untuk memudahkan para peserta memahami dan mempraktikkan membuat laporan keuangan. Panduan dibuat secara singkat dan ringkas namun tidak mengurangi konsep laporan keuangan sehingga mudah dibawa dan dipahami. Panduan laporan keuangan disusun membentuk leaflet sehingga efisien waktu dan biaya. Bentuk Brosur panduan laporan keuangan pada Gambar 6.

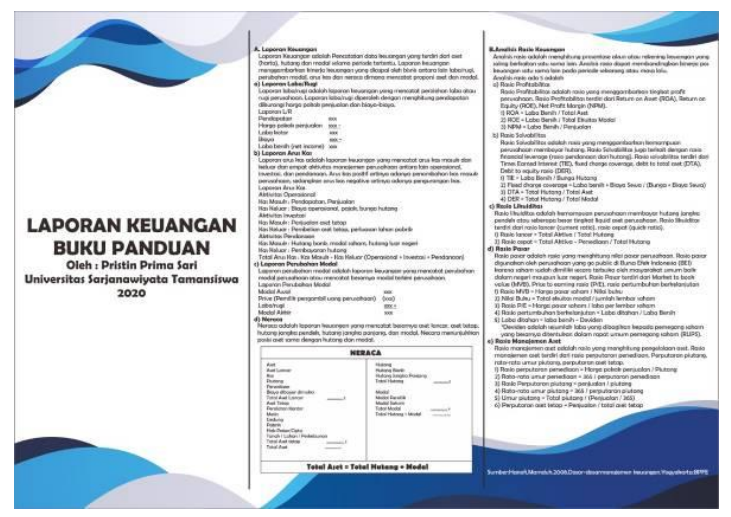

Gambar 6. Brosur Panduan Laporan Keuangan

\section{Peningkatan Pemahaman Peserta Kegiatan}

Tabel 1. Peningkatan pemahaman peserta

\begin{tabular}{lllll}
\hline No & \multicolumn{1}{c}{ Nama } & Pre & Pasca & \% \\
\hline 1 & Anna & 60 & 90 & 50 \\
2 & Eni & 50 & 80 & 60 \\
3 & Haryanti & 55 & 85 & 54 \\
4 & Irawanti & 55 & 90 & 63 \\
5 & Endah & 60 & 90 & 50 \\
6 & Tri Mulyatini & 65 & 95 & 50 \\
7. & Daliya & 60 & 80 & 33 \\
8. & Fitri & 60 & 80 & 33 \\
9. & Sulistyowati & 55 & 80 & 45 \\
10. & Susilowati & 60 & 85 & 41 \\
11. & Nanik & 65 & 90 & 38 \\
12. & Ummi & 65 & 95 & 46 \\
13. & Siti Salma & 50 & 90 & 80 \\
14. & Mardiana & 50 & 80 & 60 \\
15. & Sarjiati & 55 & 85 & 54 \\
16. & Rahayu & 55 & 85 & 54 \\
17. & Muhdi & 65 & 85 & 30 \\
18. & Linggar & 60 & 80 & 33 \\
19 & Atun & 55 & 80 & 45 \\
20. & Yuli & 55 & 80 & 45 \\
21 & Budi & 60 & 85 & 41 \\
\hline & Rata-Rata & 57.8 & 85.2 & 48 \\
\hline Sumbri Data diolah & $(2019)$ & & \\
\hline
\end{tabular}

Sumber: Data diolah (2019) 
Tabel 1 menunjukkan bahwa nilai rata-rata spebelum pelatihan 57,8 dan setelah pelatihan 85,2 , sedangkan peningkatan pemahaman mencapai nilai $48 \%$. Pada awal sebelum pelatihan Para peserta telah dapat mengetahui fungsi dan manfaat laporan keuangan, namun belum dapat mengenali bentuk-bentuk laporan keuangan dengan baik dan benar. Setelah pelatihan para peserta mengalami peningkatan pemahaman sebesar $48 \%$ dimana peserta dapat membuat laporan keuangan dengan benar seperti laporan laba/rugi, neraca dan perubahan modal dan arus kas.

Laporan Keuangan adalah Pencatatan data keuangan yang terdiri dari aset (harta), hutang dan modal selama periode tertentu. Laporan keuangan menggambarkan kinerja keuangan yang dicapai oleh bisnis antara lain laba/rugi, perubahan modal, arus kas dan neraca dimana mencatat proporsi aset dan modal. Pembuatan laporan keuangan dapat mengetahui arus kas masuk dan keluar yang berguna untuk menjaga tingkat likuiditas keuangan (Sari dan Putra, 2020). Pembuatan Laporan keuangan juga merupakan sebuah evaluasi keuangan bisnis sehingga mengetahui tingkat kesehatan keuangan (OJK, 2015).

Laporan keuangan terbagi menjadi empat jenis antara lain laporan laba/rugi, laporan arus kas, laporan perubahan ekuitas dan Neraca (Hanafi, 2008). Laporan laba/rugi diperoleh dari pencatatan pendapatan dikurangi biaya operasional. Neraca adalah posisi atau kondisi keuangan perusahaan. a) Laporan Laba/Rugi

Laporan laba/rugi adalah laporan keuangan yang mencatat perolehan laba atau rugi perusahaan. Laporan laba/rugi diperoleh dengan menghitung pendapatan dikurangi harga pokok penjualan dan biayabiaya.

\section{Laporan L/R}

Pendapatan $\quad \mathrm{xxx}$

Harga pokok penjualan $\underline{x x x}-$

Laba kotor $\quad x x x$

Biaya $\underline{x x x}-$

Laba bersih (net income) $x x x$

b) Laporan Arus Kas

Laporan arus kas adalah laporan keuangan yang mencatat arus kas masuk dan keluar dari empat aktivitas manajemen perusahaan antara lain operasional, investasi, dan pendanaan. Arus kas positif artinya adanya penambahan kas masuk perusahaan, sedangkan arus kas negative artinya adanya pengurangan kas.

\begin{tabular}{|l|}
\hline Laporan Arus Kas \\
\hline Aktivitas Operasional \\
Kas Masuk : Pendapatan, Penjualan \\
Kas Keluar : Biaya operasional, pajak, \\
bunga hutang \\
Aktivitas Investasi \\
Kas Masuk : Penjualan aset tetap \\
Kas Keluar : Pembelian aset tetap, \\
perluasan lahan pabrik \\
Aktivitas Pendanaan \\
Kas Masuk: Hutang bank, modal \\
saham, hutang luar negeri \\
Kas Keluar : Pembayaran hutang \\
Total Arus Kas : Kas Masuk - Kas \\
Keluar (Operasional + Investasi + \\
Pendanaan) \\
\hline
\end{tabular}

c) Laporan Perubahan Modal

Laporan perubahan modal adalah laporan keuangan yang mencatat perubahan modal 
perusahaan atau mencatat besarnya modal terkini perusahaan.

Laporan Perubahan Modal

Modal Awal xxx

Prive

Laba/rugi

Modal Akhir

$(x x x)$

d) Neraca

Neraca adalah laporan keuangan yang mencatat besarnya aset lancar, aset tetap, hutang jangka pendek, hutang jangka panjang, dan modal. Necara menunjukkan posisi aset sama dengan hutang dan modal. Bentuk neraca ada pada Gambar 7.

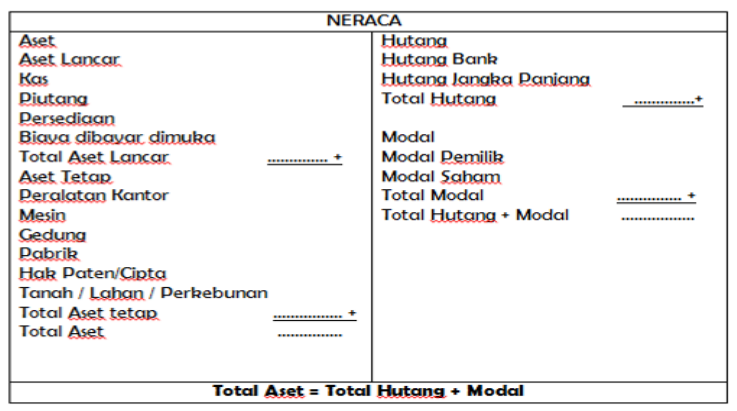

Gambar 7. Neraca

\section{Monitoring dan Evaluasi}

Pada saat pelaksanaan pengabdian para peserta berperan aktif sehingga materi yang disampaikan dapat dipahami dengan baik. Ibu-Ibu Wirogunan sangat mengapresiasi kegiatan pelatihan karena dapat mendorong mereka untuk menerapkan disiplin keuangan dan pembuatan laporan keuangan. Kelebihan kegiatan ini adalah kegiatan terlaksana dengan baik dan tepat waktu. Ibu-Ibu dapat mengikuti kegiatan pelatihan laporan keuangan sampai selesai. Adapun kekurangan sesi tanya jawab tidak dapat menjangkau kepada seluruh peserta karena keterbatasan waktu dan kesempatan antara tim pengabdian dan para peserta. Hambatan pada saat pelaksanaan adalah waktu yang dimiliki peserta kegiatan tidak lama sehingga pemberian materi pengabdian harus dipercepat. Peluang adanya kegiatan antara lain Kegiatan pelatihan laporan keuangan dapat menjadi peluang untuk kesuksesan finansial bagi para IbuIbu Wirogunan. Dengan ketertiban membuat laporan keuangan maka para pelaku bisnis dapat disiplin dalam mengelola keuangan bisnis dan keluarga sehingga memudahkan pengambilan keputusan bisnis. Kesuksesan finansial bagi para pelaku usaha harus dikembangkan agar mencapai kesejahteraan keluarga. Strategi kesuksesan finansial dapat disosialisasikan kedepannya.

\section{KESIMPULAN}

Kegiatan Pengabdian bertujuan untuk memberikan meningkatkan literasi laporan keuangan dan disiplin keuangan melalui bentuk pelatihan membuat laporan keuangan. Peserta pelatihan adalah Ibu-Ibu Wirogunan Yogyakarta. Pelaksanaan kegiatan adalah tanggal 5-6 Agustus 2019 di Pendopo Kelurahan Wirogunan Yogyakarta. Metode pelatihan adalah ceramah, tanya-jawab dan praktek laporan keuangan. Hasil kegiatan adalah Para peserta dapat memahami laporan keuangan dengan prosentase peningkatan sebesar $48 \%$ dan nilai akhir sebesar 85,2. Manfaat kegiatan adalah untuk memberikan pemahaman dan ketrampilan tentang pembuatan laporan keuangan dan teknik disiplin keuangan dalam bisnis dan keluarga. Luaran kegiatan adalah brosur laporan keuangan bisnis kecil. 


\section{UCAPAN TERIMA KASIH}

Tim Pengabdian Mengucapkan banyak terima kasih kepada:

1. Kepala LP3M Universitas Sarjanawiyata Tamansiswa

2. Ibu Lurah Wirogunan

3. Ibu-Ibu Wirogunan

4. Mahasiswa Prodi Manajemen Universitas Sarjanawiyata Tamansiswa.

\section{DAFTAR PUSTAKA}

Abadi, R. (2016). The Power of Sinergi. Jakarta: Gramedia.

Abdillah, M., Primasari, D., Widianingsih, R. (2019). Pengaruh Strategi Bisnis, Kemampuan Managerial, Dan Pengetahuan akuntansi Pelaku UMKM terhadap Kinerja UMKM Bidang Kuliner Kabupaten Purbalingga. Jurnal Optimum, 9 (2), September 2019.

Cahyani, P.D., Maharani, B.D., dan Hutami, L.T.H. (2019). Motivasi Wirausaha dan Pelatihan Penganggaran Serta Pembukuan Pada Ibu-Ibu PKK Pedukuhan Wonocatur. Jurnal JAPI Unitri, Vol 4, No 2, Oktober 2019.

Hanafi, M. (2008). Dasar-Dasar Manajemen Keuangan. Yogyakarta: BPFE Yogyakarta.

Herawati, J., Kusumaningrum, N., Sari, PP \& Maulida, A. (2019). Pelatihan Kewirausahaan: Membuat Kue Tradisional Dan Promosi Digital di Pujokusuman Kelurahan Keparakan Kecamatan Mergangsan Kota Yogyakarta. Jurnal Wasana Nyata 3 (2) September 2019.
Herawati, J., Tria, L., Hutami, H., \& Sari, P.P. (2019). Pelatihan Kewirausahaan Pembuatan Dan Promosi. Jurnal Abdimas Dewantara, 2(1), 1-7.

Hermuningsih, S., Widiastuti, R., dan Kurniawan, R.B. (2017). Preferensi Selera Profil Usaha (Business Profile Appetite) Pada Program Kewirausahaan Mahasiswa (Studi Kasus Pada Mahasiswa di Universitas Sarjanawiyata Tamansiswa Yogyakarta). Diskusi Panel Nasional Pendidikan Kewirausahaan, LPPM Unindra Jakarta.

Mumpuni, D.L. \& Sari, P.P. (2019). Financial Attitude dan Akses Kredit Formal Usaha Kecil di Taman Sari Yogyakarta. Jurnal Optimum, 9(1), 30-44.

Otoritas Jasa Keuangan (OJK). (2015). Booklet Literasi Keuangan.

Rinofah, R., Kurniawan, S. (2016). Analisis Kelayakan Usaha Warung "Burjo" (Studi Kasus di Dusun Karang Gayam, Catur Tunggal, Depok Sleman, Yogyakarta). Jurnal Kewirausahaan dan Bisnis, 19(10), 1-11.

Rinofah, R., Sari, PP. (2019). Peran Mediasi Capaian Keuangan : Pengaruh Mengelola Keuangan dan Kepuasan Finansial Pedagang Pasar Beringharjo Yogyakarta. Jurnal Kewirausahaan dan Bisnis, 23 (1).

Sari, P.P. (2019). Manajemen Usaha Kecil. Yogyakarta: CV. Samudra Biru.

Sari, P.P \& Putra, A.P. (2020). Manajemen Keuangan Bisnis. 
Yogyakarta: CV. Samudra Biru.

Setiabudi, J. (2008). Kitab Anti

Bangkrut. E-Book.

Widarwati, N.T., Gama, B., Putra, A.P. (2017). Pelatihan Bahasa Inggris Bagi Guru TK di Kalurahan Dukuh, Kecamatan Mojolaban Sukoharjo. Prosiding Seminar Nasional \& Internasional 2017: Prosiding Implementasi Penelitian Pada Pengabdian Menuju Masyarakat Mandiri Berkemajuan Publisher: Universitas Muhammadiyah

Semarang. 